\title{
Development of secretory immunity in breast fed and bottle fed infants
}

\author{
S STEPHENS
}

Division of Communicable Diseases, Clinical Research Centre, Harrow, Middlesex

SUMmARY Samples of saliva and nasal secretions were collected sequentially from 15 breast fed and 15 bottle fed infants on five occasions between 6 days and 9 months of age. Total immunoglobulin concentrations of G, M, and A classes, and class specific antibodies to tetanus toxoid and a pool of commensal strains of Escherichia coli were measured by solid phase radioimmunoassay and expressed per milligram of total protein. There were significant differences between feeding groups, which changed with age. Total IgM and IgA concentrations and $\operatorname{IgA}$ antibodies to $E$. coli were higher in the saliva and nasal secretions of breast fed infants at 6 days. There followed a rapid increase in IgM and $\operatorname{IgA}$ concentrations in secretions from all infants, and between 6 weeks and 9 months concentrations were higher in the saliva (but not in the nasal secretions) of the bottle fed group. There were no significant differences between the feeding groups for total IgG, specific $\mathrm{G}, \mathbf{M}$, and A antibodies to tetanus toxoid, and $\mathrm{G}$ and $\mathrm{M}$ antibodies to $E$. coli.

These results suggest that breast feeding enhances secretory immunity in the early neonatal period only. By 6 weeks, local antigens are the main source of stimulation for production of immunoglobulin in the respiratory mucosa and thus may be obscuring any additional stimulation by growth factors in breast milk.

The lower morbidity and mortality found in breast fed infants compared with bottle fed infants is a consequence not only of a reduction in the incidence of gastrointestinal tract infections but also of a reduced incidence of respiratory tract infections. ${ }^{1} 2$ Human milk contains a number of antimicrobial compounds, including specific antibodies to respiratory pathogens, ${ }^{3}$ which are thought to be important in conferring this increased protection. Although milk contains large quantities of immunoglobulins (particularly $\operatorname{IgA}$ ), their absorption into the blood of the neonate has been reported as low or absent in full term human infants, ${ }^{4}$ and a local passive protective role for the immunoglobulins and other antimicrobial proteins in milk has been postulated. ${ }^{5}$ A third possibility is that other soluble factors in breast milk might be absorbed and enhance the development of active immunity in the breast fed infant. Factors in breast milk with such potential have been shown in vitro. ${ }^{6-10}$ Studies of infant mononuclear cells indicate these factors have a role in vivo, ${ }^{11}$ but enhancement of secretory immunity in breast fed infants has been disputed. ${ }^{12-16}$ The secretory immune system is relatively immature at birth, and when $\operatorname{IgM}$ and $\operatorname{IgA}$ are measured by immunodiffusion they are often below the level of detection. ${ }^{12}{ }^{16}$ In this study, therefore, we have used a more sensitive radioimmunoassay to determine the development of immunoglobulin and specific antibody concentrations in the saliva and nasal secretions of 30 breast and bottle fed infants followed from birth until 9 months of age.

\section{Materials and methods}

Subjects and samples. All subjects were healthy full term infants born at Northwick Park Hospital. Twelve of 15 breast fed infants were fed exclusively on breast milk from birth to 4 months of age and fully weaned beyond $71 / 2$ months; the other three were fully weaned at 2 months. All bottle fed infants received cow milk formula from birth (SMA Gold Cap). Infants were vaccinated from 3 months of age with triple vaccine (diphtheria, tetanus, pertussis) containing $60 \mathrm{IU}$ adsorbed tetanus toxoid. Mothers were requested not to feed their infants for at least two hours before collection of samples. Nasal secretion samples were collected by placing a 
polyvinyl catheter (Blue line umbilical cannula, Portex Ltd, Hythe, Kent) into the nasopharynx and applying gentle suction. Catheters were rinsed in $200 \mu \mathrm{l}$ phosphate buffered saline, and washings were stored at $-70^{\circ} \mathrm{C}$. Samples were tested for contamination with blood using Hemastix (Ames). Mucoid samples were homogenised with $10 \mathrm{mM}$ dithiothreitol in Tris/ $\mathrm{HCl}$ buffer, $\mathrm{pH} 8 \cdot 0$.

Whole saliva samples were collected by placing a polyvinyl catheter under the tongue and applying suction. Samples were stored at $-70^{\circ} \mathrm{C}$. Thawed saliva was homogenised by forcing it repeatedly through a fine bore pasteur pipette. When insufficient saliva was available to test undiluted, samples were diluted in phosphate buffered saline and results expressed per milligram of total protein.

Total protein estimations. Total protein was estimated using a protein dye binding assay based on the principle that the binding of Coomassie brilliant blue dye to protein causes a shift in the absorption maximum of dye from 465 to $595 \mathrm{~nm}$. The Bio-Rad protein kit (Bio-Rad Laboratories, W Germany) was used with a bovine $\gamma$ globulin standard. Standards or samples were diluted to give 1-30 $\mu \mathrm{g}$ protein in $1 \mathrm{ml}$ phosphate buffered saline. To this was added $250 \mu \mathrm{l}$ Bio-Rad reagent. Samples were vortex mixed, and colour development was measured 10-60 minutes after at $595 \mathrm{~nm}$ on a spectrophotometer (Perkin-Elmer model 6/20).

Solid phase radioimmunoassay. The method for quantitation of total immunoglobulins and specific antibodies to tetanus toxoid and E. coli is described in detail elsewhere. ${ }^{17}$ Briefly, flexible plates (Linbro) were coated with rabbit antihuman IgG, IgM, or IgA ( $\alpha$ chains and secretory component) (Dakopatts, Copenhagen), tetanus toxoid $(2 \mathrm{ng} / \mathrm{ml})$, or $E$. coli ' $\mathrm{O}$ ' antigen pool, extracted from six commensal strains common in the London area. Remaining sites were blocked with a buffer containing $0.2 \%$ bovine serum albumin, $0.2 \%$ gelatin, and $0.1 \%$ sodium azide concentrations. Serial dilutions of standards, infant saliva, nasal secretion, or serum samples were added. Standards used were a human IgG monoclonal antibody to tetanus toxoid, an IgM myeloma, IgA purified from colostrum, and an affinity purified anti-E. coli serum. Bound immunoglobulins or antibodies were measured by addition of ${ }^{125}$ I labelled anti-IgG, - IgM, or - IgA (100 cps). A control row was included for each sample, and this non-specific binding was subtracted from test results. The minimum sensitivity of this technique for detecting immunoglobulin or specific antibody was $10-20 \mathrm{ng} / \mathrm{ml}$ of undiluted sample. For washings of nasal secretions, the minimum sensi- tivity per mg of protein was inevitably reduced. The specificity for the relevant immunoglobulin class was high, with less than $0 \cdot 1 \%$ binding to other immunoglobulin classes.

Statistics. Results of tests for immunoglobulin and specific antibody concentrations were log transformed to normalise the distribution and expressed as geometric means with $95 \%$ confidence intervals. Comparisons between feeding groups were made using analysis of variance, and significance was assessed by the $F$ test.

\section{Results}

Total immunoglobulins in saliva samples. Figure 1 shows the geometric means of the results expressed per $\mathrm{mg}$ of total protein. IgG concentrations declined from $1.6 \mu \mathrm{g} / \mathrm{mg}$ at 6 days to $0.3 \mu \mathrm{g} / \mathrm{mg}$ between 3 and 6 months then rose to $0.5 \mu \mathrm{g} / \mathrm{mg}$ by 9 months. There were no significant differences between feeding groups. IgM was detectable $(>20 \mathrm{ng} / \mathrm{mg})$ in 12 of 23 infants at 6 days; concentrations increased between 6 days and 6 weeks but remained fairly stable from 6 weeks to 9 months. There was a significant effect of feeding group, which changed with age $(F=4 \cdot 76$, $p=0 \cdot 0013)$. At 6 days IgM concentrations were higher in the breast fed than the bottle fed infants $(0.14 \mu \mathrm{g} / \mathrm{mg}$ and $0.024 \mu \mathrm{g} / \mathrm{mg}$, respectively). By 6 weeks, concentrations of IgM were higher in the bottle fed group $(0.55 \mu \mathrm{g} / \mathrm{mg}$ for breast fed and 1.6 $\mu \mathrm{g} / \mathrm{mg}$ for bottle fed), and this difference was maintained beyond 9 months. IgA was detectable at 6 days in all the breast fed and in six of 13 bottle fed infants. IgA concentrations also increased dramatically from 6 days to 6 weeks and then declined slightly between 6 weeks and 9 months. Again there was a highly significant difference between the feeding groups, which changed with age $(F=17$, $\mathrm{p}<0.0001)$. IgA was significantly higher in the breast fed group at 6 days $(2.2 \mu \mathrm{g} / \mathrm{mg}$ for breast fed and $0.05 \mu \mathrm{g} / \mathrm{mg}$ for bottle fed) but by 6 weeks was slightly higher in the bottle fed group $(37 \mu \mathrm{g} / \mathrm{mg}$ for breast fed and $54 \mu \mathrm{g} / \mathrm{mg}$ for bottle fed).

Although at 6 days no samples of saliva were obtainable in sufficient quantity to test undiluted, between 6 weeks and 9 months enough sample material was available from most infants to make measured dilutions and express the results per millilitre of saliva. These figures showed a similar pattern to results expressed per mg total protein, with greater IgM concentrations in the bottle fed group on all occasions after 6 weeks (Table). Most undiluted samples of saliva contained $1-2 \mathrm{mg} / \mathrm{ml}$ total protein. 
Correlation of serum and salivary IgA concentrations. For breast fed infants there was a significant correlation between serum and salivary IgA concen- trations on three of five sampling occasions ( 6 weeks and 6 and 9 months) and a high degree of overall correlation $(r=0 \cdot 579, \mathrm{p}<0 \cdot 001)$. There was, how-

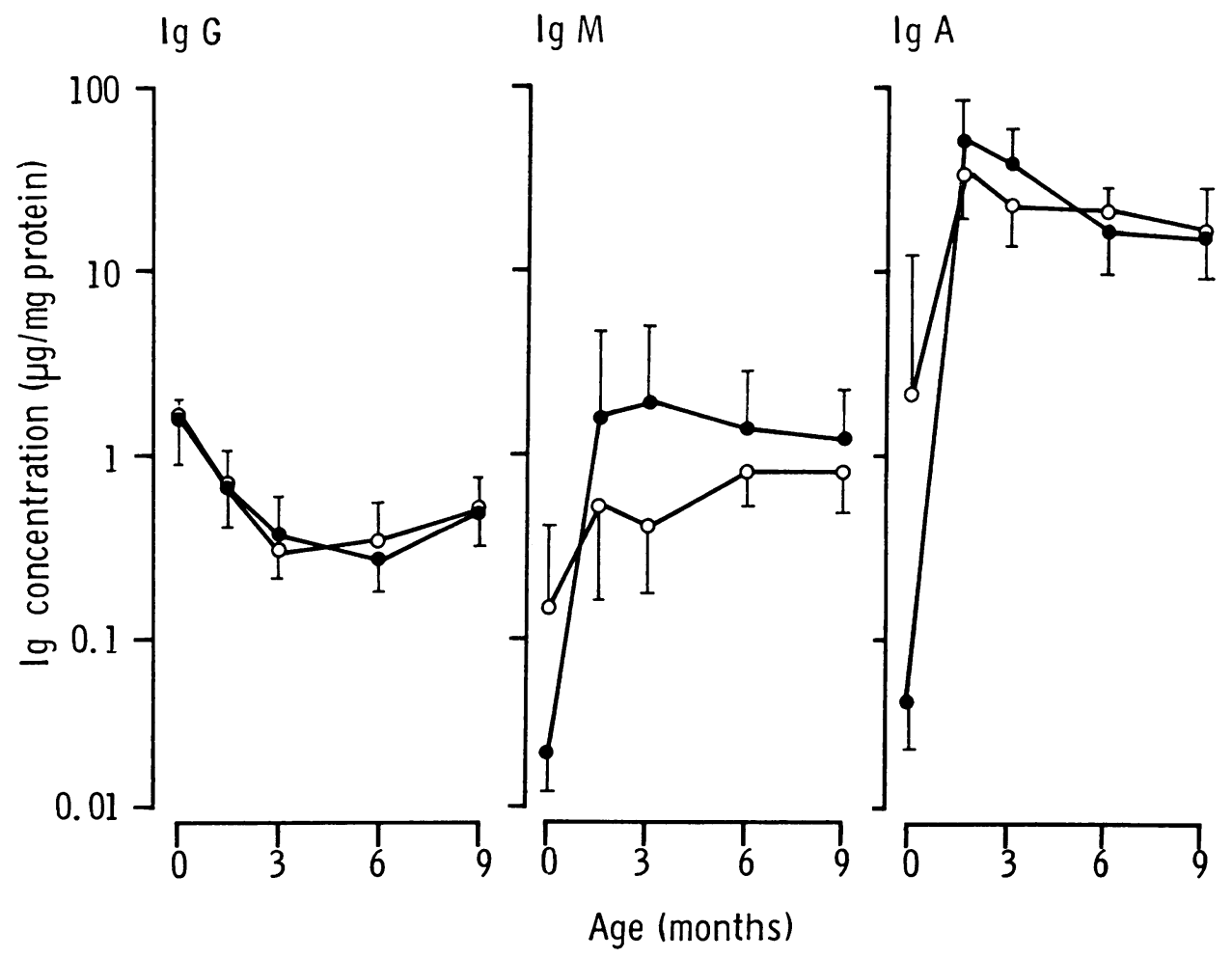

Fig. 1 Immunoglobulin concentrations in saliva samples from breast $(\bigcirc)$ and bottle fed (O) infants. Results are expressed as geometric means with $95 \%$ confidence intervals $(n=12-15)$.

Table Immunoglobulin concentrations in infant saliva expressed per millilitre undiluted sample. Values are geometric means $(95 \%$ confidence intervals) in $\mu \mathrm{g} / \mathrm{ml}$

\begin{tabular}{|c|c|c|c|c|}
\hline Age: Feeding group & $n=$ & $\lg C$ & $\lg M$ & $\lg A$ \\
\hline \multicolumn{5}{|l|}{6 weeks: } \\
\hline Breast & 10 & $1 \cdot 05(0 \cdot 5-2 \cdot 4)$ & $0.47(0.1-1.9)$ & $61 \cdot 7(26 \cdot 3-141 \cdot 3)$ \\
\hline Bottle & 12 & $0.89(0.5-1.7)$ & $1.14(0.4-4.8)$ & $93 \cdot 3(45 \cdot 7-190 \cdot 6)$ \\
\hline \multicolumn{5}{|l|}{3 months: } \\
\hline Breast & 14 & $0.50(0.3-() \cdot 8)$ & $0.53(0 \cdot 2-1 \cdot 5)$ & $33 \cdot 1(18 \cdot 6-60 \cdot 3)$ \\
\hline Bottle & 14 & $0.68(0.3-1.4)$ & $3.31(1.01-10.5)$ & $77 \cdot 6(10 \cdot 7-151 \cdot 4)$ \\
\hline p value & & & 0.017 & 0.048 \\
\hline \multicolumn{5}{|l|}{6 months: } \\
\hline Breast & 15 & $0.42(0.3-1) \cdot 6)$ & $1 \cdot(0)(0 \cdot 6-1 \cdot 7)$ & $25 \cdot 7(16 \cdot 2-39 \cdot 8)$ \\
\hline Bottle & 15 & $0.45(0.3-0.7)$ & $2 \cdot 51(1.3-4 \cdot 9)$ & $26 \cdot 3(16 \cdot 2-41 \cdot 7)$ \\
\hline p valuc & & & 0.022 & \\
\hline \multicolumn{5}{|l|}{9 months: } \\
\hline Breast & 15 & $0.72(0.5-1.0)$ & $0.96(0 \cdot 6-1 \cdot 8)$ & $24.55(14 \cdot 8-40 \cdot 7)$ \\
\hline Bottle & 14 & $0.82(0.6-1 \cdot 1)$ & $2 \cdot 40(1 \cdot 3-4 \cdot 5)$ & $28 \cdot 84(19 \cdot 5-42 \cdot 7)$ \\
\hline p value & & & $0 \cdot(140$ & \\
\hline
\end{tabular}

Differences hetween groups on individual occasions were assessed by pooled $t$ test. 
ever, no correlation in the bottle fed group, either overall $(r=0.092)$ or on any individual sample occasion.

Total immunoglobulins in nasal secretion samples. Figure 2 shows IgG, IgM, and IgA concentrations per $\mathrm{mg}$ protein in nasal secretions. Proportions of IgG were 10 -fold higher in nasal secretions than in saliva $(15 \mu \mathrm{g} / \mathrm{mg}$ nasal secretion; $1.6 \mu \mathrm{g} / \mathrm{mg}$ saliva at 6 days). The change in IgG concentrations with age was similar to that found in saliva, with a decline until 3 months $(5 \mu \mathrm{g} / \mathrm{mg})$ and then a gradual increase up to 9 months. Concentrations were greater in the breast fed group on all occasions, and when the changes with age were taken into account the difference between feeding groups was significant $(F=3.95, p=0.049)$. Concentrations of IgM were slightly higher in nasal secretions than in saliva on each occasion. IgM was detectable in all infants by 6 days of age (all $>40 \mathrm{ng} / \mathrm{mg}$ ) and increased with age up to 3 months. IgM concentrations were slightly higher in the breast fed than the bottle fed group, but this difference was not significant. IgA concentrations in nasal secretions were similar to those in saliva. At 6 days IgA was detectable in samples from all but one (bottle fed) infant. There was a rapid increase in IgA between 6 days and 6 weeks, then concentrations remained stable between 3 and 9 months. The difference between feeding groups was highly significant and changed with age $(F=4.91$, $\mathrm{p}=0.0011$ ). This difference was maximal at 6 days when $\operatorname{Ig}$ A concentrations were higher in the breast fed group $(1 \mu \mathrm{g} / \mathrm{mg}$ for breast fed and $0.07 \mu \mathrm{g} / \mathrm{mg}$ for bottle fed).

Correlation of IgM and IgA in samples from 6 day old infants with time since last breast feed. Although mothers were requested not to feed their infants for at least two hours before sample collection, this did not always prove practicable, and 6 day samples were collected between one and four hours after feeding. To determine whether those samples collected soonest after feeding contained the highest concentrations of $\operatorname{IgM}$ or $\operatorname{IgA}$, immunoglobulin concentrations in saliva were correlated with the time since the last intake of breast milk. No significant correlation was found for $\operatorname{IgM}(r=0.039)$ or $\operatorname{IgA}(r=0 \cdot 004)$.



Fig. 2 Immunoglobulin concentrations in nasal secretion samples from breast and bottle fed infants $(O=$ breast fed, $=$ bottle fed). Results are expressed as geometric means with $95 \%$ confidence intervals. 
Specific antibodies in saliva and nasal secretions. Twenty 'saliva samples from breast and bottle fed infants aged between 6 weeks and 9 months were tested for class specific antibodies to tetanus toxoid. No $\operatorname{IgM}$ or $\operatorname{IgA}$ antibodies were detected $(>10$ $\mathrm{ng} / \mathrm{ml}$ ), but one infant had low concentrations of IgG antibodies to tetanus toxoid $(135 \mathrm{ng} / \mathrm{ml})$. This infant also had the highest response of serum IgG antibody to tetanus toxoid of all the infants ( 315 $\mu \mathrm{g} / \mathrm{ml}$ ). Twenty six samples of nasal secretion were tested for IgM and IgA antibodies to tetanus toxoid. None had IgM antibody, and three had low concentrations of $\operatorname{IgA}$ antibody (mean $190 \mathrm{ng} / \mathrm{mg}$ ). Of 96 samples tested for IgG antibody, nine had detectable antibodies (mean $37 \mathrm{ng} / \mathrm{mg}$ ). There were no significant differences between the feeding groups.

IgG antibodies to $E$. coli were detectable in only one of 20 saliva samples tested $(90 \mathrm{ng} / \mathrm{ml})$, and IgM antibodies to $E$. coli were detected in four of 32 samples $(60-100 \mathrm{ng} / \mathrm{ml})$. IgA antibodies to $E$. coli were detectable in 127 of 141 saliva samples. Figure 3 shows the geometric means. At 6 days $\operatorname{IgA}$

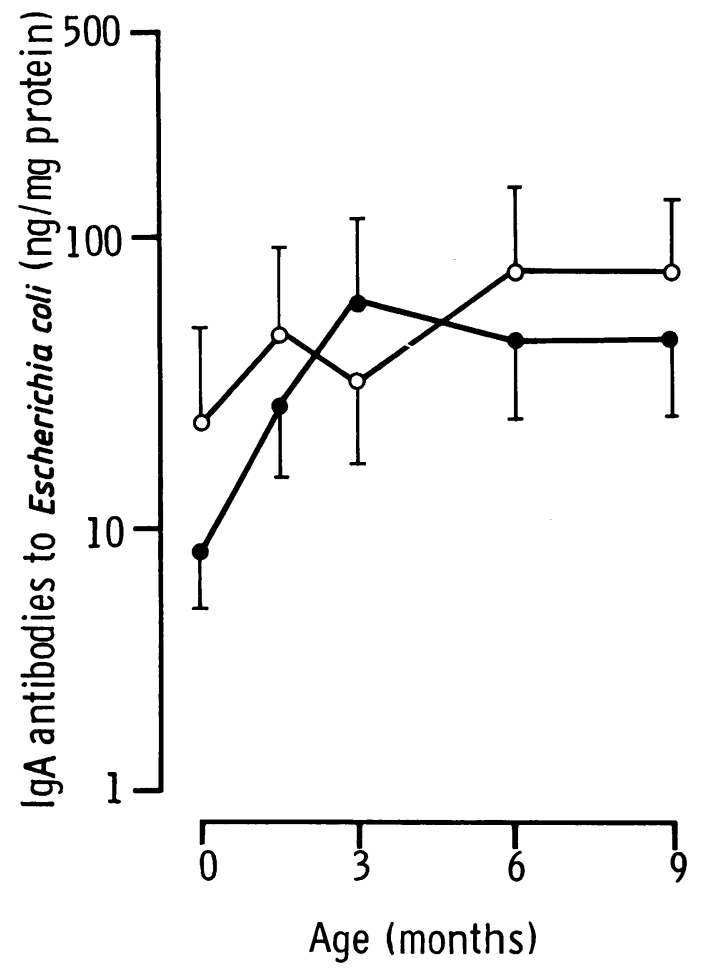

Fig. 3 Specific IgA antibodies to lipopolysaccharide antigens from a pool of six commensal Escherichia coli strains. Results are expressed as geometric means with $95 \%$ confidence intervals $(\mathrm{O}=$ breast fed, $\mathrm{O}=$ bottle fed $)$. antibody was detectable $(>10 \mathrm{ng} / \mathrm{mg})$ in seven of 11 breast fed and two of 13 bottle fed infants. The higher concentration found in breast fed infants was significant $(p=0 \cdot 0089)$. By 6 weeks $\operatorname{IgA}$ antibodies to $E$. coli were detectable at low concentrations in all infants $(10-300 \mathrm{ng} / \mathrm{mg})$. There were no significant differences between the feeding groups between 6 weeks and 9 months.

Nasal secretion samples contained low concentrations of $E$. coli antibodies: three of 88 had detectable IgG antibodies (mean $31 \mathrm{ng} / \mathrm{mg}$ ) and four of 88 had detectable IgM antibodies (mean $32 \mathrm{ng} / \mathrm{mg}$ ). IgA antibodies were detected in 16 of 88 nasal secretion samples (nine breast fed, mean $83 \mathrm{ng} / \mathrm{mg}$; seven bottle fed, mean $64 \mathrm{ng} / \mathrm{mg}$ ). These specific antibodies were short lived, generally being undetectable by the next sampling occasion. There were no significant differences between the feeding groups.

\section{Discussion}

Studies on secretory immunity in breast and bottle fed infants have given conflicting results due to differences in the time and method of sample collection, sensitivity of techniques used, and methods of expressing results. ${ }^{12-16}$ In this study we have used a sensitive radioimmunoassay technique capable of detecting as little as $10 \mathrm{ng} / \mathrm{ml}$ immunoglobulin or specific antibody and have compared the development of secretory immunoglobulins and specific antibodies in saliva and nasal secretions from 30 infants studied sequentially from 6 days to 9 months of age. Results have been expressed in relation to total protein, but comparison with concentration per millilitre of undiluted sample showed similar results.

At 6 days IgM and IgA were detectable $(>40$ $\mathrm{ng} / \mathrm{mg}$ ) in nasal secretions from all but one infant and in saliva from most breast fed and half the bottle fed infants. Concentrations increased dramatically in both feeding groups between 6 days and 6 weeks and remained fairly constant from 6 weeks to 9 months. The differences between the feeding groups were highly significant and changed with age. The largest differences occurred in the early neonatal period (6 days), when breast fed infants had significantly more IgM and IgA in both types of secretion than bottle fed infants. Other workers have also found significantly more $\operatorname{IgA}$ in saliva and nasal secretions from breast fed infants during the first week of life. ${ }^{13-15}$ Contamination of infant secretions by milk $\operatorname{IgA}$ is one possible reason for these findings, but even when food was withheld for over four hours before sample collection Gross and Buckley found IgA concentrations were still three to 
six times higher in breast fed infants during the first week of life. ${ }^{13}$ Other investigators who have claimed to have found no difference between the feeding groups have often used techniques that were insufficiently sensitive to detect the small amounts of $\operatorname{IgA}$ or IgM present in the secretions of newborn infants. ${ }^{12} 16$ In this current study, although mothers were requested not to feed their infants for as long as possible before sample collection, it was considered impracticable to withhold food when the infants were obviously hungry, and some samples were therefore collected within two hours of breast feeding. There was no significant correlation, however, between the time since feeding and the concentrations of $\operatorname{IgA}$ or $\operatorname{IgM}$ in the secretions of exclusively breast fed infants, and some 6 day old breast fed infants still had high concentrations of IgA four hours after feeding. Clearly, if this is due to residual milk $\operatorname{IgA}$ then the passive protective effect is lasting well beyond the disappearance of milk from the oral cavity, possibly helped by the attachment of milk $\operatorname{IgA}$ to buccal epithelial cells. ${ }^{18}$ The possibility of milk being regurgitated into the nasopharynx has been discussed by other workers. ${ }^{15}$ Although contamination by milk immunoglobulins may account for some of the higher IgA concentrations, the question of enhanced IgA secretion by the breast fed infant remains. The demonstration of several growth factors and lymphocines in human milk, ${ }^{7-10}$ including a factor that stimulates cord blood cells to differentiate into IgA secreting cells, ${ }^{8}$ may be significant. The enhanced proliferative responses of peripheral blood mononuclear cells from these infants at 6 days $^{11}$ gives further support to this theory.

The dramatic increase in $\operatorname{IgM}$ and $\operatorname{IgA}$ in nasal secretions and saliva from both breast and bottle fed infants between 6 days and 6 weeks is almost certainly due to a response to environmental antigens and colonisation of the respiratory mucosa by micro-organisms, with a resulting polyclonal expansion of lymphoid cells. The response seems relatively greater in bottle fed infants, who had lower baseline concentrations at 6 days. Certainly, by 6 weeks IgA concentrations in nasal secretions and saliva were comparable for the two feeding groups, in spite of the fact that 12 of the 15 breast fed infants were still being exclusively breast fed at this time and were therefore passively receiving large quantities of milk $\operatorname{IgA}$. This milk $\operatorname{IgA}$, in addition to providing passive protection, will also shield the mucosal immune system of the breast fed infant from antigenic stimulation by preventing adhesion and replication of micro-organisms on the mucosal surface. The significantly greater IgM concentrations in the saliva (but not nasal secretions) of the bottle fed infants compared with the breast fed? infants may be caused also by the constant stimula-으 tion of lymphoid cells in their oral cavities by cow $\overrightarrow{\vec{\omega}}$ milk proteins, which are known to be highly antigenic and to give rise to large quantities of serum antibodies in bottle fed infants. ${ }^{19}$ The strong correla- $\frac{\bar{\sigma}}{\bar{c}}$ tion of salivary and serum $\operatorname{IgA}$ in the breast fed but $\frac{\bar{\Phi}}{\Phi}$ not the bottle fed infants, is unlikely to be due to absorption of $\mathrm{IgA}^{4}$ but could be due to absorption of soluble factors that may regulate both local and $\overrightarrow{0}$ systemic IgA secretion. Lack of correlation in the bottle fed group may simply reflect the independent $\vec{\omega}$ routes of local and systemic antigenic stimulation.

Specific antibodies to tetanus toxoid, an antigen $\stackrel{\circ}{\Omega}$ administered as part of the infants' vaccination protocol, were low or undetectable in saliva and $\vec{\omega}$ nasal secretions. The one infant who had IgGiv antibody to tetanus toxoid in saliva also produced the largest serum IgG response to this antigen, ${ }^{17}$ and 을 the IgG antibody in saliva is, therefore, likely to be $\rightarrow$ due to transfer from serum rather than local 3 synthesis; the concentration of specific antibody in saliva represented only $0 \cdot 04 \%$ of the serum concen- $\frac{\rho}{J}$ tration. Specific IgA antibodies to a pool of com- $\overrightarrow{0}$ mensal $E$. coli ' $\mathrm{O}$ ' antigens were detectable in secretions from all infants by 9 months of age but only at low concentrations $(<0 \cdot 1 \%$ total IgA), in spite of the presence of a large serum IgM and lower serum $\operatorname{IgA}$ response to these antigens. ${ }^{17}$ Other workers have also shown low concentrations of $\frac{\mathrm{Q}}{\mathbb{Q}}$ antibodies to $E$. coli in the saliva of European $\varrho$ infants. ${ }^{20}$ Comparisons between the feeding groups $\overrightarrow{\vec{O}}$ indicated significantly higher antibody concentra- 3 tions in the breast fed group at 6 days of age only.

Breast feeding may therefore have contrasting? effects on the development of secretory immunity. Growth factors in milk have the potential to? stimulate proliferation and differentiation in lym- $\frac{\sigma}{3}$ phoid tissue $^{610}$ and may be an important aspect of . $^{-}$ the protective benefits of breast feeding, particularly $ᄋ$ in the early neonatal period. At the same time, immunoglobulins and specific antibodies in human milk, while conferring passive protection, will shield $D$ the local immune system of the breast fed infant from antigenic challenge, which would itself cause $\bar{N}$ specific and non-specific proliferation of lymphoid tissues. Such antigenic stimulation may be relatively harmless when caused by commensal gut flora or $\mathrm{N}$ cow milk proteins, but the implications are more serious when potential pathogens are involved.

The author thanks Dr R F Tiebout and Dr W P Zcijlemaker of the Netherlands Red Cross for the IgG monoclonal antibody to tetanus toxoid and Dr P K Lakhani and Dr C R Kennedy for their help with $\frac{\vec{D}}{(10}$ the clinical aspects of this study. The work was approved by the ethical committee of Northwick Park Hospital (EC 772). 


\section{References}

1 Robinson M. Infant morbidity and mortality. A study of 3266 infants. Lancet 1951:i:788-94.

2 Watkins CJ, Leeder SR. Corkhill RT. The relationship between breast and bottle feeding and respiratory illness in the first year of life. J Epidemiol Community Health 1979:33:180-2.

${ }^{3}$ Toms GL. Gardner PS. Pullan CR, Scott M. Taylor C. Secretion of respiratory syncytial virus inhibitors and antibody in human milk throughout lactation. J Med Virol 1980;5:351-60.

${ }^{4}$ Ogra SS, Weintraub D, Ogra PL. Immunologic aspects of human colostrum and milk. III Fate and absorption of cellular and soluble components in the gastrointestinal tract of the newborn. J Immunol 1977:119:245-8.

5 Hanson LA. Winberg J. Breast milk and defence against infection in the newborn. Arch Dis Child 1972;47:845-8.

6 Pittard WB, Bill K. Differentiation of cord blood lymphocytes into IgA-producing cells in response to breast milk stimulatory factor. Clin Immunol Immunopathol 1979;13:430-4.

7 Tapper D. Klagsbrun M, Neumann J. The identification and clinical implications of human breast milk mitogen. $J$ Pediatr Surg 1979:14:803-8.

* Carpenter G. Epidermal growth factor is a major growthpromoting agent in human milk. Science 1980;210:198-9.

9 Keller MA, Kidd RM, Bryson YJ, Turner JL, Carter J. Lymphokine production by human milk lymphocytes. Infect Immun 1981:32:632-6.

11 Juto P. Human milk stimulates B cell function. Arch Dis Child 1985;60:610-3

"Stephens S. Brenner MK, Duffy SW. Lakhani PK, Kennedy CR. Farrant J. The effect of breast-feeding on proliferation by infant lymphocytes in vitro. Pediatr Res 1986: (in press).
12 Gleeson M, Cripps AW, Clancey RL, Husband AJ, Hensley MJ, Leeder SR. Ontogeny of the secretory immune system in man. Aust NZ J Med 1982;12:255-8.

${ }^{13}$ Roberts SA, Freed DLJ. Neonatal IgA secretion enhanced by breast feeding. Lancet 1977;ii:1131.

${ }^{14}$ Gross SJ, Buckley RH. IgA in saliva of breast-fed and bottle-fed infants. Lancet 1980;ii:543.

15 Taylor CE, Toms GL. Immunoglobulin concentrations in nasopharyngeal secretions. Arch Dis Child 1984;59:48-53.

16 Ostergaard PAA. Serum and saliva Ig-levels in infants of non-atopic mothers fed breast milk or cow's milk-based formulas. Acta Paediatr Scand 1985;74:555-9.

17 Stephens S, Kennedy CR, Lakhani PK, Brenner MK. In vivo immune responses of breast- and bottle-fed infants to tetanus toxoid antigen and to normal gut flora. Acta Paediatr Scand 1984;73:426-32.

${ }^{18}$ Roberts SA, Wincup G, Harries DA. Mucosal receptor for IgA in the breast-fed neonate. Early Hum Dev 1980;4:161-6.

${ }^{19}$ Kletter B, Gery I, Frier S, Davies AM. Immune responses of normal infants to cow milk. II. Decreased immune reactions in initially breast-fed infants. Int Arch Allergy 1971;40:667-74.

${ }^{20}$ Mellander L, Carlsson B, Jalil F, Soderstrom T, Hanson LA. Secretory IgA antibody response against Escherichia coli antigens in infants in relation to exposure. $J$ Pediatr 1985;107:430-3.

Correspondence to Dr S Stephens, Clinical Research Centre, Division of Communicable Diseases, Watford Road, Harrow, Middlesex HA1 3UJ.

Received 26 November 1985

\title{
58th Annual Meeting of the British Paediatric Association
}

\author{
15-19 April 1986, University of York.
}

Copies of the printed programme, including abstracts, are available at a cost of $£ 3$ each from: BPA, 5 St Andrews Place, Regents Park, London NW1 4LB. 